\title{
A Journey in North-Western Arabia
}

\section{Author(s): Douglas Carruthers}

Source: The Geographical Journal, Vol. 35, No. 3 (Mar., 1910), pp. 225-245

Published by: geographicalj

Stable URL: http://www.jstor.org/stable/1777459

Accessed: 29-04-2016 10:22 UTC

Your use of the JSTOR archive indicates your acceptance of the Terms \& Conditions of Use, available at

http://about.jstor.org/terms

JSTOR is a not-for-profit service that helps scholars, researchers, and students discover, use, and build upon a wide range of content in a trusted digital archive. We use information technology and tools to increase productivity and facilitate new forms of scholarship. For more information about JSTOR, please contact support@jstor.org.

The Royal Geographical Society (with the Institute of British Geographers), Wiley are collaborating with JSTOR to digitize, preserve and extend access to The Geographical Journal 


\section{The}

\section{Geographical Journal.}

No. 3.

MARCH, 1910.

VoL. $\mathbf{X X X V}$.

\section{A JOURNEY IN NORTH-WESTERN ARABIA.*}

By DOUGLAS CARRUTHERS.

DURING the last twenty-five years our knowledge of the interior of Arabia has not been increased in any way. Although Arabia still possesses the largest tract of unknown country in the world, it has been neglected by travellers, and its exploration has been at a standstill for a quarter of a century. In 1908, however, Captains Aylmer and Butler opened up new ground in Northern Arabia, filling in a long existing blank between Bagdad and Jauf. Mr. D. G. Hogarth's paper in the Geographical Journal for December, 1908, also drew attention to the remaining fields of exploration in South-Western Asia, and more especially in Arabia. I therefore determined to make an effort to travel over and map out the blank that exists between the Hejaz railway and the Wadi Sirhan, to determine the western limits of the Great Nafud, and to visit the oasis of Teima. Thence I proposed to proceed to Hail, and if possible to follow the Wadi el Rumma down to its junction with the Euphrates river. Teima attracted me because it had not been entered by a European for twenty-six years, and the interest of Hail lay in the fact that there is no up-to-date account of the affairs of the rival Emirs of Hail and Riad, nor of the present state of Nejd.

In January, 1909, through the medium of the American College in Beirut in Syria, I obtained funds to enable me to plan an expedition in search of rare animals that inhabit the northern frontiers of Arabia. In fact, I might almost say that it was a rare antelope, namely, the Arabian oryx, which induced me to launch forth into those inhospitable deserts, and was the "load-star" that led me on across the deserts to the borders of Nejd, in Central Arabia. Although the chief object of my

* Read at the Royal Geographical Society, January 24, 1910. Map, p. 356.

No. III.-MARCH, 1910.] 
journey was natural history, yet in a land so poor in fauna, I had time and opportunity to further geographical knowledge, and to render an account of these regions in the fullest manner possible.

In January, 1909, I set out from Damascus, and journeyed down the Mecca railway as far as the oasis of Tebuk, on the threshold of Arabia proper. From here I tried to pass into the interior, but found it impossible, owing to the hostility of the Beduin and the watchfulness of the Turkish officials. The Hejaz railway hinders the traveller rather than helps him, for the tribes are hostile to the building of the line, and Turkey has no power amongst the Beduin. Moreover, the pure Arabs of the oasis in the interior are still more watchful, and more determined than ever to stop any but Moslems from entering their "forbidden land."

I spent two weeks at Tebuk. The tribe of the Beni Atiye held the surrounding country, and although I was safe within their borders, I could not go further. So I returned to Damascus to seek an easier method of getting to my goal. My plan of action was to make friends with some powerful Beduin tribe, who could help me on my way into Arabia. In order to do this, it was necessary to find a man to act as guide and friend, and to introduce me to one of the great tribes. Such a man I found in Muhammad Mirawi, a native of Damascus, who had wandered all over Arabia, and had come in contact with most of the great tribes. He had acted as camel-dealer and transport agent for the Haj to Mecca, and had even traded camels from Central Arabia for the Egyptian Government. In fact, being a man of importance, he see ned to suit my purpose exactly, and I engaged him. He was an old man, too old, it seemed, to be setting out on such a journey; but age is greatly respected amongst the Beduin, and his knowledge of the affairs of East and West made him a very superior person amongst the ignorant nomads, who, however, always have a thirst for knowledge.

In Damascus I bought up camel-saddles, water-skins, and such food as rice, flour, coffee, and sugar; rifles and cartridges for my men, and a few presents of clothes for the Beduin. In fact, I bought everything I needed for a journey in a foodless and waterless country. It was necessary for me to change all my money into the Austrian dollars (the Maria Teresa), which are in demand all over Central Arabia in preference to the Turkish money. My only need then was transport, and this I could not get except among the Beduin, for I wanted dromedaries of the finest breed. Thus I had to introduce myself to one of the great tribes that hold the borderlands, and own large herds of camels. For without these a journey into the waterless interior would be impossible. I chose for my purpose the tribe of the "Beni Sakhr," or "Children of the Rock," who hold the marches of Palestine and Arabia. Hearing that they were wandering in the neighbourhood of Katrane, which was an old blockhouse on the Haj route to Mecca, 
and is now the position of a station on the Hejaz railway, I made use of the train as far as the village of Jesi, some 40 miles to the north of the former place.

Jesi is situated about 22 miles due east of the Dead sea, in the Belka country, and is of interest as being the limit of cultivation. To the east of this all is desert. This country is a transition stage between the "desert and the sown," the rolling downs are covered with a certain amount of growth, and in the spring there is very good pasturage. Indeed, all the year round there is sufficient to support large herds of camels and flocks of sheep and goats.

The "Belka," then, is the headquarters of the Beni Sakhr, and from it they get their strength and wealth, for they have a good land to fall back on, with a certain good supply, and are not dependent on the open desert with its shifting and uncertain pastures. This is their base, where they can keep their herds in safety and without fear of loss from drought, and it is from here that they range over the country to the eastwards.

The "Beni Sakhr" tribe have the reputation of being the boldest robbers, for their numbers are great and, being rich, possess good rifles, therefore I thought it prudent to make friends with the strongest tribe. The exact range of the Beni Sakhr is from the Druse country south of Jebel Druse to Maan. The declivities of the Jordan valley and the Dead sea form their western boundary, whilst eastwards they wander as far as the Wadi Sirhan. South-eastwards they occasionally make use of the Sherrarat country, with which tribe they are allies, but their migrations in that direction are limited by the territory of the Howeitat, their most deadly enemies. The Beni Sakhr are true nomads, in that they do not cultivate, and always live in tents; but they are of a less migratory habit than the tribes, such as the Roala and Sherrarat, who wander over the inner deserts.

On my arrival at Jesi, I found that the Beduin were encamped in the country to the south-east, and with the aid of a party of Arabs going out to join the tribe, I eventually found myself, after a journey of thirteen hours, drawing within view of an immense encampment of Beduin. There were probably a thousand tents scattered over the boundless waste, pitched in long lines in the wadis, or in any slight depression which would protect them from the wind. Over the surrounding country immense numbers of camels wandered, herded by half-naked Beduin boys. I sought the tent of the sheikh, Hathmel ibn Zeben, who proved a good friend, and showed true Arab hospitality by entertaining me and my men for three weeks.

By living with the Arabs, doing as they did, and moving with them in their migrations, I obtained an insight into their mode of life and customs, which helped me a great deal during my subsequent journey. I found them most friendly and willing to help, but I kept 
from them iny real intentions, and only told them I needed to purchase camels for a journey. Things move slowly in the East, and I spent fourteen days in buying three camels! But the time was not wasted. I studied Arab manners, learned more or less how to eat with my hands, and how to wear Arab costume with some comfort, how to drink coffee à la Arab, and, most difficult of all, how to sit still all day long doing nothing. I found this last most trying, more especially because it was cold; a Beduin tent is a draughty place at the best, but in mid-winter it is almost unbearable. On two occasions there was snow on the desert.

We used to feed out of a huge round dish, ten of us at a time. The fare was camels' milk and bread in the morning, and in the evening we generally had meat and rice, cooked with an enormous amount of fat. During the day we appeased our hunger by sipping strong black coffee. At night there was always a large group of men in the tent of the sheikh, and talk was carried on far into the night. The vexing question of pasture had always to be considered, and when and whither the tribe should move. Srnall matters and tribal quarrels had to be settled, and there was never a day but news came in of the raids and warfare of the other tribes, news of the rival emirs in the heart of Arabia, and of the fighting between Turk and Beduin along the Hejaz railway.

My man from Damascus was most popular at these evening discussions, for he always had some story to recount or some news to tell, and if ever there was lull in the conversation, he would be turned on to describe adventures he had met with on his travels. Eloquence is a highly prized talent amongst the Beduin, and not only would they recount their stories in the most beautiful manner, but on occasion, to the tune of a single-stringed violin, they would sing extempore songs for hours on end.

One day, when in our wanderings we happened to camp near some rolling country, the sheikh and I rode off in search of gazelle. We found a large herd, and being mounted on good horses we managed to ride them down, throwing ourselves off our horses for the shot, then galloping on again. We killed six gazelle in about an hour, and rode back to camp with enough meat for a big feast.

It is the custom that whoever kills game should provide a feast for all his friends. On the occasion of these feasts I noticed that there was always a crowd of hangers-on waiting at the end for a scrap of food-half-starved looking boys and ragged men. These were orphans, whose parents had been killed, or men whose herds had been "lifted" by other Arabs, and as a result they were destitute, for the law of the Beduin is "survival of the fittest" in its strictest sense. But the sheikh supplied food liberally, and I noticed that he always looked after the poor and fed the hungry. 


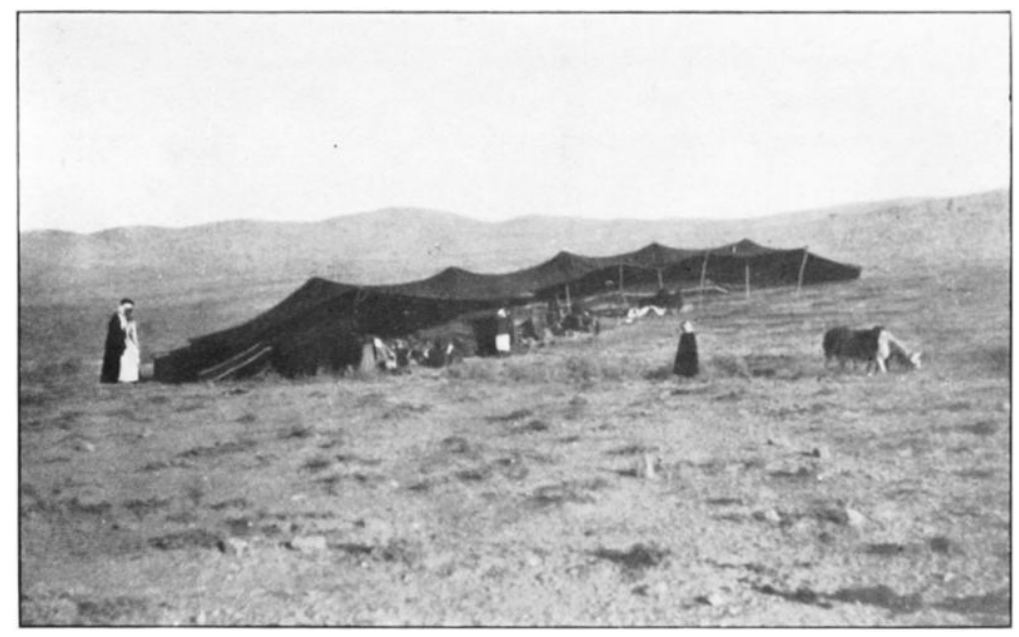

THE GREAT TENT OF SHEIKH HATHMEL OF THE BENI SAKHR.

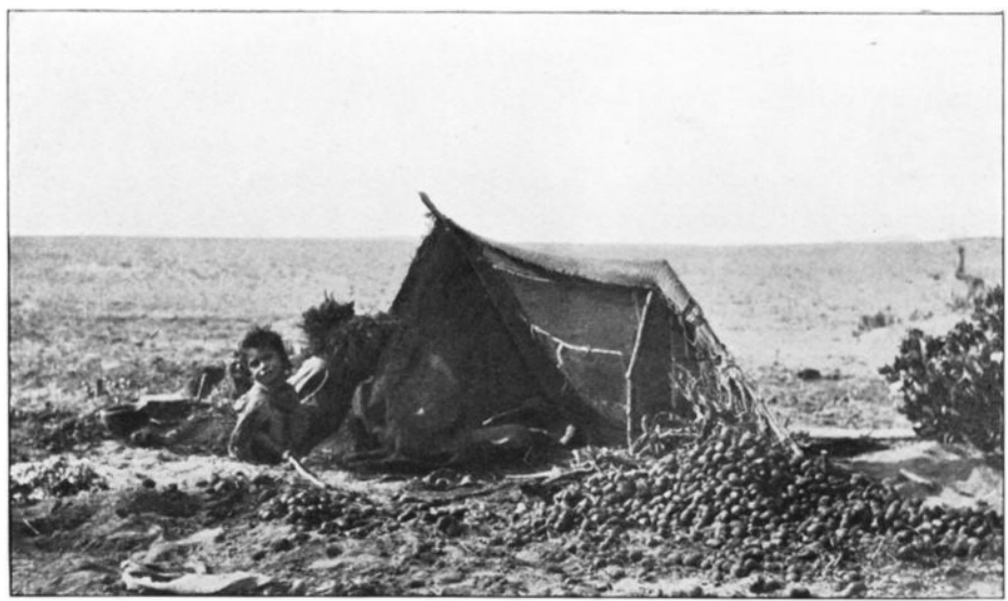

SMALL TENT BELONGING TO THE SHERRARAT BEDUIN.

This content downloaded from 134.129.182.74 on Fri, 29 Apr 2016 10:22:00 UTC All use subject to http://about.jstor.org/terms 


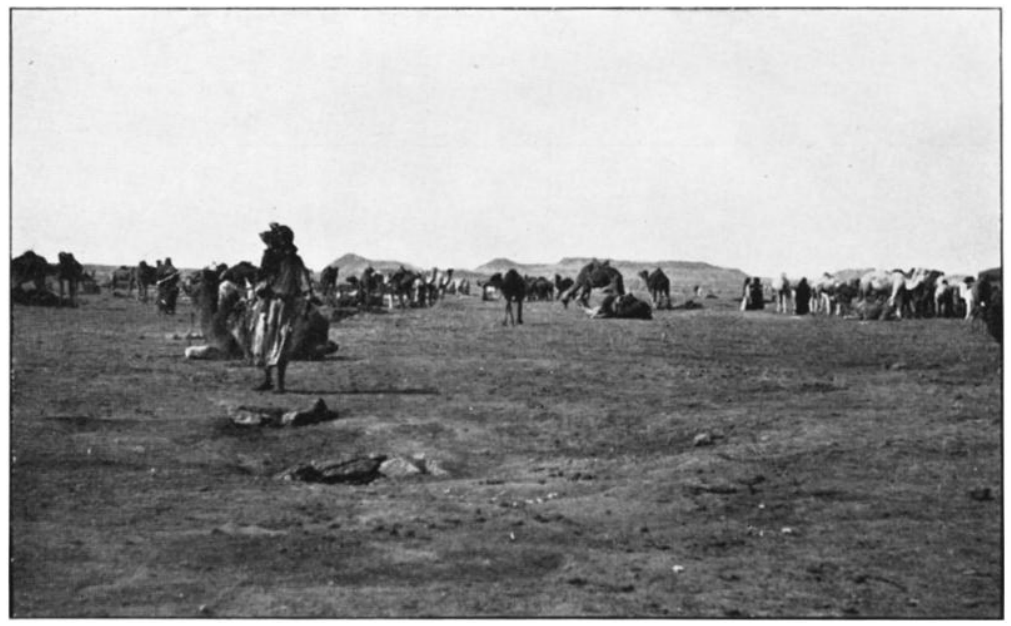

CAMEL-HERDS AT A WELL.

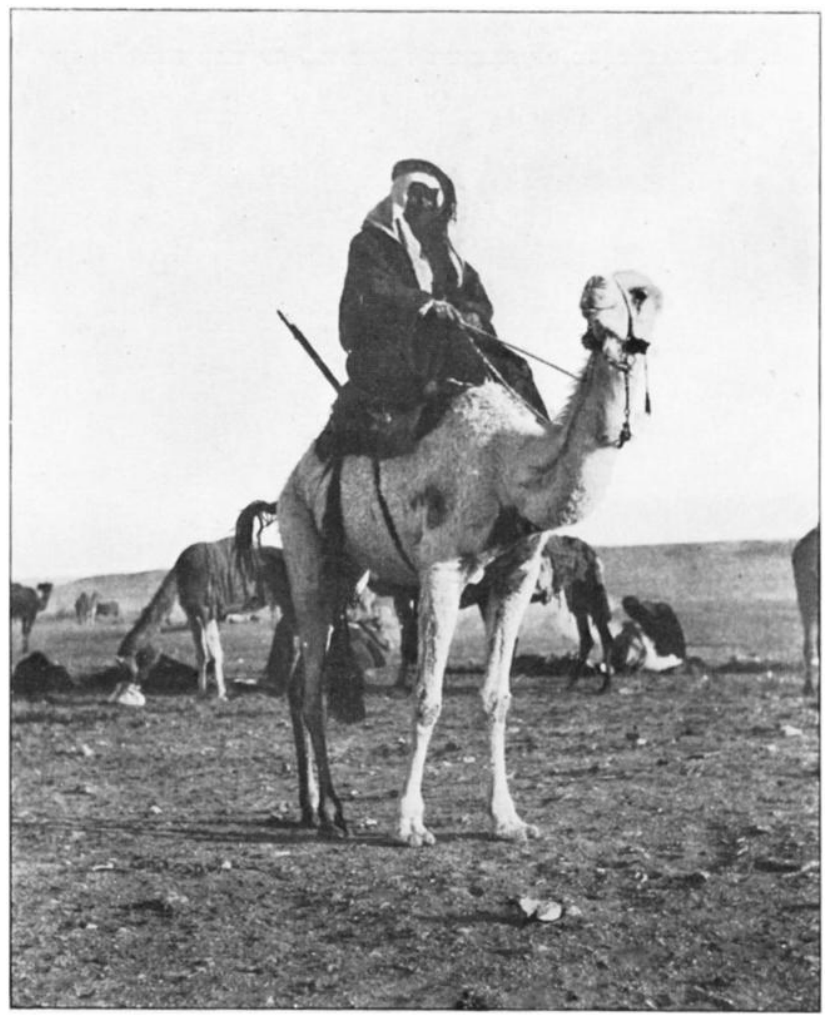

A BEDUIN WARRIOR (SHERRARAT TRIBE). 
The tent that I lived in all this time was the ordinary black "beit," as used by all the nomadic tribes. It is interesting to note that the same name is used for "house" in the settled districts, a remnant of the time when all the Arabs were nomadic. The tents varied in size, but not in design. The poor Sherrarat had tiny little tents scarcely big enough to protect two people from the sun and wind, for they were nothing more than screens to shield the owners from the elements. An average tent measured perhaps 20 yards by 6 yards, but the tent of the sheikh was a structure that spread over a length of 36 yards by 8 yards deep. The colour was always dark chocolate-black, the back only being striped longitudinally with white. All the tents of the Beni Sakhr were like this, but the little tents of the Sherrarat were of a greater mixture of çlour. The large tents were all divided across the middle by a brightly coloured curtain to partition off the women's quarters. In all cases the front of the tent is open the whole length. They are pitched facing to leeward, and if the wind changes round they merely take off the back and put it up on the other side, thereby changing the front of the tent.

This tribe owned immense herds of camels, a large number of sheep, and sufficient horses to mount all their fighting men. They live almost entirely on the produce of their herds, and have but little need of money. The camel provides them with meat, milk, clothes, house, and transport. Their whole lives are given up to the breeding of their flocks and herds, and to systematic robbery. The Beduin lives in his tent for a week at a time, or until the fit comes over him, and he calls his companions, and off they go on a foray to steal camels, in order to increase their own herds. The Arab's great idea is to possess a rifle, for that means power. In order to do this he must steal camels. So, having stolen camels, he purchases a rifle; then come more raids to take more camels, this time in order to buy a wife. Camels are their sole means of exchange.

During this time we constantly changed camp, and wandered across the desert in search of new pasture, for the grazing was not sufficient in any one place to support the herds of camels for any length of time. At dawn I used to find the camp astir, and the tents being taken down by the women, and rolled up into huge bales, while the boys herded the camels, and the men loaded them up with the household impedimenta. When the camels were laden, the small children were lifted on to the top of the loads, where they seemed perfectly at home. Then, when all was in readiness, the migration began, and each family, with its own compact little caravan, set off across the desert.

One by one each little home was packed up, and moved off to pastures new. First of all went the camel-herds, driven by lads and lasses; these were followed by the camels, laden with the tents, campkit, and small children; the women walked by the side, or rode, 
perched on the top of a tent-load, singing wild Beduin songs as they moved, heedless of their poverty, but revelling in their freedom. The men, armed and on horseback, rode far in advance or at the rear on the look-out for enemies, scouting the country in search of pasture, sometimes indulging in a course after a hare with their greyhounds, or loosing their falcons at a "houbara" bustard. Hares, bustard, sand-grouse, and gazelle abounded on these rolling plains, and I saw many a pretty hunt with hound and hawk.

It is a fine sight to see a large encampment on the move, imbued with the spirit of "divine unrest." The Children of Israel must have presented just the same spectacle when they wandered of old from well to well, for the Arab never changes. When the chief finds a suitable grazing-ground, he lights a fire as a signal to the rest of the tribe, who are scattered over a large stretch of desert. The smoke of the fire shows the nomads the position of the chief's tent, and they gather round and pitch theirs in groups, generally in depressions to get shelter from the wind. It takes very little time to put up the tents and to get everything in order, and then the Arabs lie about and talk and drink much coffee, until the spirit moves them to go on a foray, or necessity forces them to shift camp again.

One evening the monotony was varied by the scare of an attack by a hostile tribe, and the news was passed through the camp in an incredibly short space of time, the cry for horsemen being taken up from tent to tent. The whole camp was in a turmoil in a second. Every man who owned a horse, or who could borrow one, armed, mounted, and galloped off, the women standing at the tent doors to wave them farewell. Men who had no "mounts" went on foot, and the boys were busy herding the camels nearer to the tents, for in Beduin warfare the camp itself is never entered, nor are the tents molested. Thus all able-bodied men can go off to fight, and leave the camp without fear of their belongings being pillaged. The scare turned out to be nothing in particular-a passing raiding-party had chanced on our encampment, but had beat a hasty retreat on finding out our numbers and strength.

As of old, the Beduin's " hand is against every man's." They are daring robbers, and think nothing of killing if ought is to be gained thereby. They have, indeed, reduced robbery to an art, and their one alleviation from the dull monotony of life is systematic robbery. These desert-rangers correspond exactly to the polite highwaymen of our own English high-roads of a hundred years ago. They are always spoiling for a fight, and the young Beduin, who are at all ambitious, find this their only means of becoming powerful.

A rifle is the wish of every young Arab, and, when he has got this, he enters on a career of plunder, in order to possess a good number of camels. Every Beduin in Northern Arabia owns a breech-loading 
rifle. I examined a great number of these, and found them to be chielly of British manufacture. There were also a fair number of American rifles, and a few French.

I seldom saw a Beduin praying; in fact, they seemed to me to be utterly careless of religion; and it is certainly remarkable that, although Arabia is the centre of the Moslem world, yet a third of its inhabitants care nothing for Islam. The nomads are not religious, and never were; they would rob a Mecca pilgrim as readily as they would a Christian. Mohammed never converted the nomad tribes.

During my stay with the Beduin I had been endeavouring to buy good camels for my journey. The remark that I wanted camels drew out long stories of record rides, and extraordinary distances covered without water, arguments as to the best breeds of dromedary, and their respective qualities. Camels form the chief concern in the Arab's existence, for, as I have said, they supply him with all his wants, and even his wife is purchased by means of camels. Hence the breeds are well selected, and the pedigrees carefully kept. There are several wellknown and highly prized kinds, and I endeavoured to obtain the best, for my journey was to be of the severest nature, and if the camels fail in a waterless country, the results are apt to be disastrous. Many camels were brought to me, but most of them were refused, for I had an expert buyer to bargain for me who knew all the tricks of the trade, and so one by one three well-bred female dromedaries in the finest condition were bought at a cost varying from $£ 11$ to $£ 16$ apiece.

By this time I calculated that my position was about 20 miles east of Katrane. All the country to the east was unknown, and I saw that by making this my "taking-off" place, I should break new ground to the borders of Nejd, in Central Arabia. It is true that an Italian, named Guarmani, passed this way on his way to Nejd some forty-five years ago, but his account of this region is very vague. His route lay to tho west of mine, and although he described in detail the tribes he met with, and his narrow escapes from marauding Beduin, of geographical information he gave us very little indeed.

This country has also been described by Tristram, who in 1872 reached the Haj route near Khan Zebib, during an exploration of the Land of Moab. He ventured no further, but described the unknown deserts to the east by hearsay, "After three days' journey across the White or limestone country is a region of black basalt, ' a land of black stones.' This he describes as being two very long days across, and he thinks, but is not sure, it is about three days' journey from north to south; this volcanic region be calls El Hhurreh. Beyond this black stone country eastward are two days more of white ground, hilly, but with good camel pasture, and then begins a desert with nothing on it but antelopes and wild cows."

A new difficulty presented itself at this moment: I could not persuade 
any Beduin to accompany me, and act as guide across the waterless desert that I now had to face. One and all refused on the grounds that I was a Christian and therefore certain to be robbed, and that, if any harm came to me, they would be accused of having had a hand in it. At last, with great difficulty, I induced the chief to give me one of his own men, a huge "Sherrari" of the Sherrarat tribe, who eventually proved invaluable.

My arrangements being completed, having packed my goods into sacks, filled my four water-skins, and watered the camels for the last time for many days, one evening after dusk the four of us mounted on four camels, left the homely tents of the "Beni Sakhr," and set out into the night. We travelled far that night, in order to get across the danger zone that exists along the coasts of the desert sea, sleeping for a short time before daybreak, after which we pushed on again, and rode all day.

I now kept my observations as best I could, with compass and watch, noting every hour I rode, as well as the pace and direction. On camels one travels very straight, and at a very even pace, making a perfectly straight line across the boundless desert, from horizon to horizon. During the first day's ride-that is to say, at about 45 miles east of Katrane-a remarkable change took place in the nature of the country. ( $I$ use this place as a base from which to count my distances, for it is the only place near my starting-point that is well marked on all maps.) The limestone steppe changed to black desert, the rolling country, bearing a certain amount of growth, suddenly stopped, and before me was an immense smooth plain covered with rounded flints, destitute of vegetation except in the wadis. The small amount of animal life which was to be seen in the "Belka" country here became still less. No gazelle or bustards enlivened the dreariness of the scene, but there were a few small birds, and occasionally I started desert hares.

There is a good landmark for travellers, which also serves to mark the junction of the limestone and the flinty deserts. It is a group of three little hills, standing up out of the desert, and visible at a long distance-_"Thleithuwath" the Arabs call it. To the north of .this is another small ridge which the Arabs have named "the end of the flints," for Arabians from the far interior, coming up to Damascus, here leave the black stony desert, and arrive at a less forbidding type of country. Then followed several hard days of travel across the black desert called "Ard-es-Suwan," or " the desert of flints," by the Beduin. I steered a course south-east by south, and kept a very direct line.

The nature of the country was that of a wide plain, gently rolling in great folds, which, however, looked perfectly level as a whole. It was a smooth limestone floor, sprinkled over evenly with countless flints, worn smooth by the action of wind and weather, polished and glistening in the sun. Here and there sandstone spires and quaint pyramidal hills, which served as landmarks, stood up out of the desert. This great 


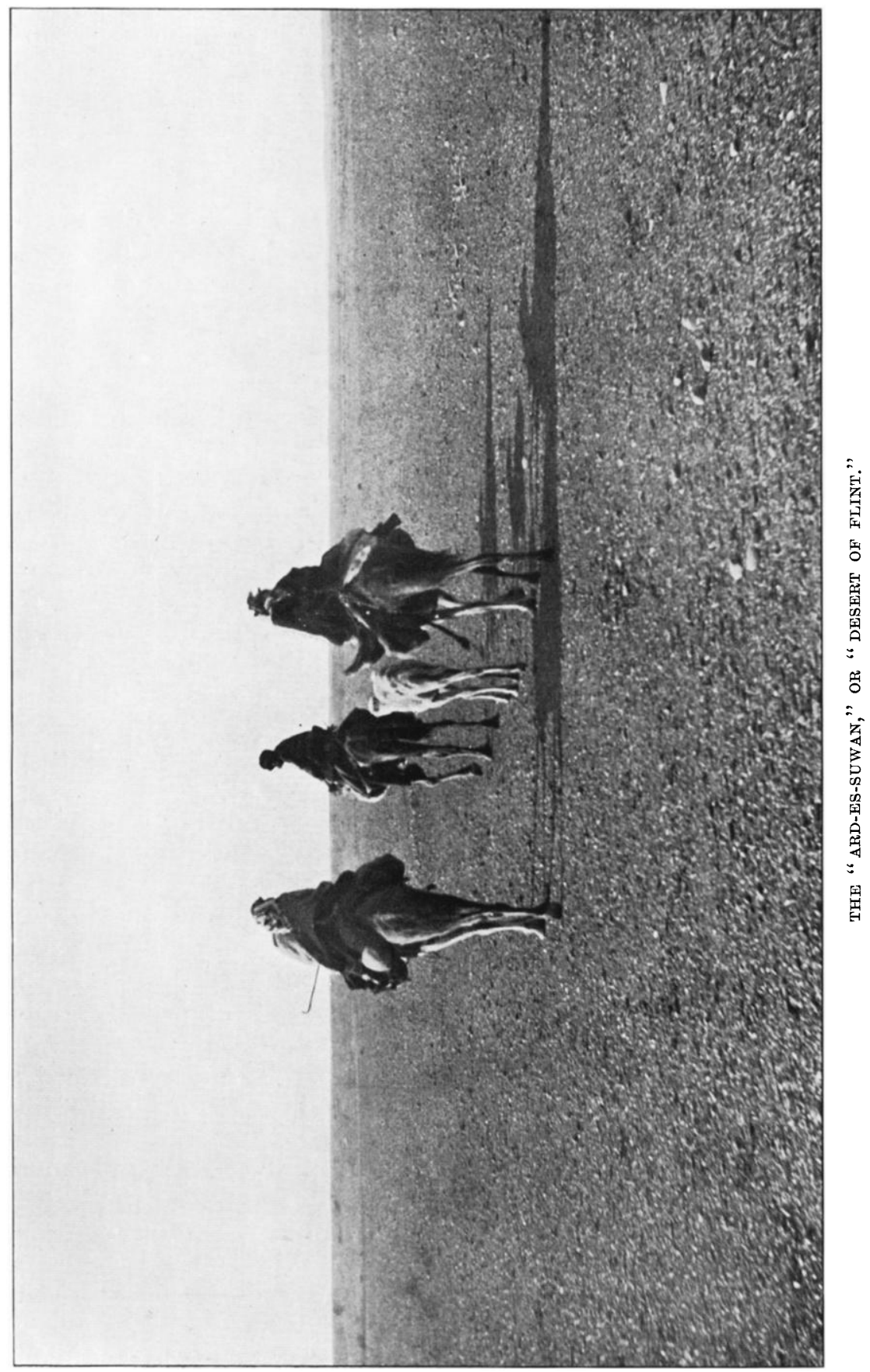

This content downloaded from 134.129.182.74 on Fri, 29 Apr 2016 10:22:00 UTC All use subject to http://about.jstor.org/terms 


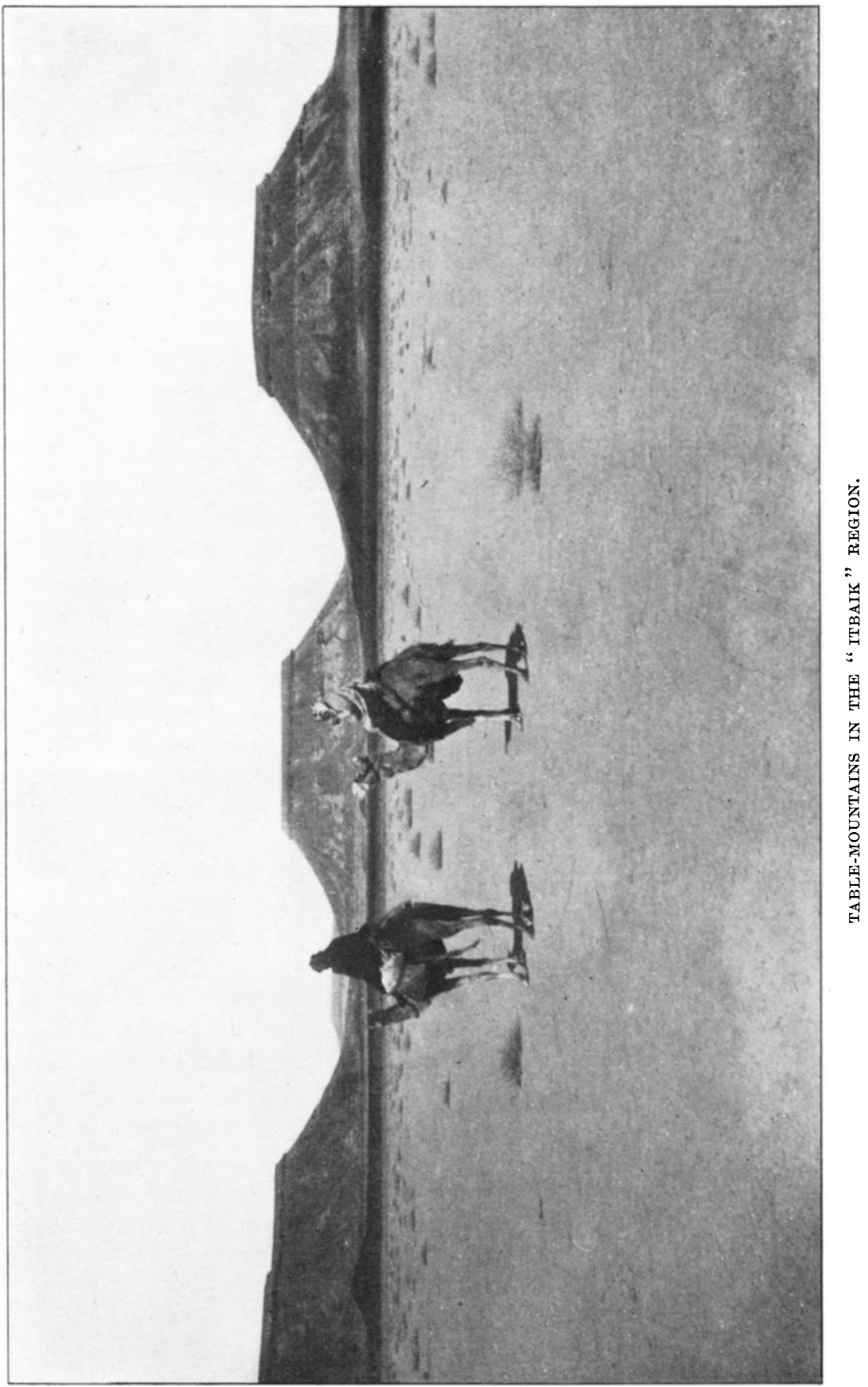

This content downloaded from 134.129.182.74 on Fri, 29 Apr 2016 10:22:00 UTC All use subject to http://about.jstor.org/terms 
black desert is not entirely featureless. The Beduin have names for every physical feature, every wadi, pasturage, and depression, every little hill and curiously shaped rock - all are considered worthy of name and notice. The altitude was high, for day after day my aneroid registered above 3000 feet, and there was very little variation in the altitude for the first five days.

The line of demarcation between the limestone and basalt deserts also marks the limit of that country where dew falls and where it does not. To the south of Wadi Bayer, the Beduin say, no dew falls, and I can testify that during the whole journey I slept out in the open and never found my clothes in the least damp.

There were many wadis intersecting my route, all of which trended in a north-easterly direction, and all flowed to the Wadi Sirhan. Three of them were especially large and important wadis, namely, Wadi Bayer, Hausa, and Hidrij, composed of deep steep-sided watercourses, and containing a considerable amount of vegetation, tamarisk, and thorn-scrub. In the dry water-channels were piled up heaps of dead wood and old trees, washed down by sudden floods. Although this land appears so sterile and rainless, yet sudden storms occur, which fill the wadis to overflowing, and cut deep channels. In these wadis is clllected all the animal life that exists, and I found innumerable colonies of sand-rats, which honeycombed the ground to such an extent that the camels sank in up to the knee-joint. These I trapped at night, for we generally slept in the wadis, and I used to skin them as I rode along the next day on camel-back.

I should much have liked to stop and collect specimens of all the fauna that inhabited this region, but lack of water forbade it, for I only had sufficient for six days. The few birds to be seen were the desert scrub-warbler (Scotocera inquieta), a chat (Saxicola leucopyga), two species of larks (Calandrella brachydactyla and Otocorys bilopha), the raven, and the ostrich. This last was an interesting discovery, for no traveller except Palgrave has mentioned sighting them in Arabia, although they have been reported by the Beduin. Presumably it is the same as the North African variety (Struthio camelus), and its occurrence in Arabia is an interesting example of a genus peculiar to Africa ranging into Asia. I saw three in the Wadi Hidrij, which is, roughly, 120 miles south-east of the Dead sea. They are found all over the interior of Arabia, but this is probably their most northerly limit. Ravens seem to find a living in the most desolate localities, and on one occasion a pair of these birds followed us, as we travelled, for a whole day across the desert, stopping when we stopped to eat, picking up the crumbs after we had left, and then following on behind.

For six days we never saw any signs of human beings, but that this region is crossed and recrossed at certain seasons by large numbers of Beduin, is evident from the well-defined tracks that mark the 
desert. The surface is hard and strong without any sand to blow about and cover up traces of footprints, and at the same time it is too hard to take an impression easily, yet the desert is tracked in all directions by smoothly worn paths, which are probably of an immense age.

To show the immensity of this land and the ease with which one could lose one's self, I may mention that we had to travel a whole day's journey without in the least knowing where we were, until my guide could pick up his bearings. Then he sighted a hill shaped like a camelsaddle just showing above the horizon, and knew our position exactly. At night we travelled by the guidance of the stars, for it was often necessary to push on at night as well as in the day. My usual plan was to travel from sunrise till eleven o'clock, then rest for two hours, and travel again till five in the evening, when we took a meal and rode on for a couple of hours in the dark before stopping for the night's sleep. I never used a tent, there was no need for it, the climate was perfect. I always slept as the Arabs did, on the ground, wrapped up in a sheepskin coat, beside my camel.

The camels during this trek had no water, of course, and very little to eat, for they never had more than two or three hours to graze every day, and there was not always sufficient to eat. This is the reason why the best camels in the finest condition at the outset are an absolute necessity. I repeatedly took these camels for periods of six and seven days without water. Nine days is the recognized limit in Arabia whilst travelling, but herds out grazing in the spring months will go for a much longer period (three weeks, it is said). In the colder climate of Central Asia the Bactrian camels will endure for nine days. I mention this because there seems to be much misapprehension as to the abilities of camels to exist without water. A recent writer in the Times states that "in Arabia the breed (of dromedaries) appears to have deteriorated, for here they will thirst perhaps for three days, after which they die, protesting. . .."

On the sixth day after leaving the tents of the Beni Sakhr the black desert ended, and I entered a region of sandstone. The whole aspect of the country altered, and before me stood a prominent range of hills, where water was said to exist, and our water-skins being empty we hurried on. The wadis now drained to the west instead of to the east into Wadi Sirhan, and I eventually found a large depression situated north of the hills called Itbaik, to which they all flowed. The well was situated in a wadi called Hausa, which is surrounded by steep hills, an outlying spur of a more extensive range further on.

Wells in such a country as this rank as a most important feature, for they make possible the existence of a large nomadic population. One well in a waterless region will support any number of shepherds, and will enable them to use as a grazing-ground a country which would otherwise remain uninbabitable for lack of drinking-water. I found 
the well of Hausa to contain the most excellent water at a depth of 40 feet.

We watered our camels and filled our water-skins as quickly as possible, for the wells are still the most frequent causes of quarrels, as in the days of old. But, quick as we were, we had an exciting moment when suddenly four Beduin appeared riding down on us in a threatening manner. They called on us to stand and deliver. But we, being the stronger party, were on the point of firing, when my guide suddenly recognized his own tribesmen, and all was well. The next minute the Beduin were kissing each other. The robbers were of the Sherrarat tribe, scouting the country on the look-out for plunder. If I had not had a man of their tribe with me there would have been a fight, and somebody, probably myself, would have lost his camels, and been left stranded in the desert. An ominous number of graves dotted the ground around the well, showing where others had been less fortunate.

In the neighbourhood of this well I saw much game. The hills were inhabited by many ibex (Capra sinaitica), and I saw some carrying very fine horns. Gazelle also were numerous here, and seemed to prefer the hill country to the open desert. I found tracks of the "cheetah," and came on the first clear traces of the Arabian oryx (Oryx beatrix). I left the well and went some way to the south-east, where I camped in order to hunt the surrounding country. The whole of this region belongs to the Sherrarat tribe, but, not being powerful, they are unable to hold it against strangers, with the result that many Beduin range over this area and render the country unsafe. It is neutral ground where many a fight takes place. Four great tribes wander round its borders, the Roala and the Beni Sakhr on the north and north-west, the Shammar on the east, and the Howeitat on the south-west. The Sherrarat, in order to save themselves from constant harrying by these stronger tribes, have become allies with them. Whenever I came across Beduin of the above-mentioned tribes, I found small encampments of Sherrarat pitched alongside of them. They are the poorest of the poor, and their tents are nothing but a shelter from the wind and sun, sometimes not sufficient to protect the whole family at once. They are fine hunters, however, and excellent shots, as their country is full of game. They also have the peculiarity of being mostly left-handed.

There are evidences to show that the interior is becoming more dry, and as a natural result the nomads find it more difficult to support themselves, and are therefore dwindling in numbers or seeking the protection of the semi-nomadic tribes who live on the edge of the cultivated lands. It is said that the Sherrarat were once a large and powerful tribe, and that their country was a "good land"; but the drought came, their herds died, and their country, which was once good pasture-land, became dry and useless. This they told me themselves, and went on to 
say that, as a result of the prolonged drought-it lasted seven yearstheir tribe divided, and the greater part migrated to Tunis. I asked them when that was, and they said, "In the days of Mohammed." This remark seems to be of the greatest interest, for it is evidence as to the desiccation of Northern Arabia. The date they gave me, the days of Mohammed, would be about 600 A.D., and this corresponds with Prof. Huntingdon's conclusions as to the desiccation of Central Asia, namely, that the period from 300 A.D. to 800 A.D. was the time of the greatest desiccation and lessening of the rainfall, which caused the western migration of the inhabitants of those regions.

Such a drought as this would affect the Sherrarat more than the other tribes, for the Sherrarat hold a region which is wholly desert. Without large wadis, where there is always pasture or oasis, they have nothing to fall back on, as the Roala have in the Wadi Sirhan, or the Beni Sakhr in the Jordan depression. Lady Ann Blunt also tells of a legend she heard in Nejd, to the effect that there was a great famine in Arabia, and the tribes migrated to Tunis.

I now reached a most interesting region called "Itbaik," which I am of an opinion is the same as the range of hills mentioned by Doughty on hearsay. He called it "Tobeyk," and it is placed somewhat vaguely on the map, rather to the north of its real position. He described it as being as high as the Irman mountains in Nejd, and as being snow. covered in winter for a considerable time. I found it to be a sandstone range, with erupted basalt rocks on the desert at the foot of the hills. The hills were a mixture of sandstone, worn black by weather, and of lava-capped sandstone piles, all of which had the appearance of flattopped table mountains. Some of these were perfectly black, and looked like immense cinder-heaps, while others were of red sandstone, with only the lava-cap showing black at the top.

The range ran east and west. Towards the east it soon faded away and was lost in high rolling country of sand-dunes and sandstone rocks ; to the west it rose up, and appeared to culminate in higher peaks of about 4000 feet. At the point where I crossed the range my aneroid registered 3600 feet. In the valleys and among the hills the ground was silted up with red sand, and there was much less vegetation on the south side than on the north. In this region of sands appeared the first "ghada" bushes, a species of salsola, which grows all over the inner sand-desert of Arabia. I think that this range of Itbaik is continuous with the ridge which borders the Hejaz railway on the east, and possibly with Jebel Sherora, that one sees to the north-east of Tebuk.

Leaving the hill country, and dropping again on to desert, after two days I found the wells of Mghairah. These wells contained good water, but of a very red colour; it was not far below the surface, and there were many well pits. Here I fell in with the main section of the Sherrarat tribe. Some two or three thousand camels were driven in to 


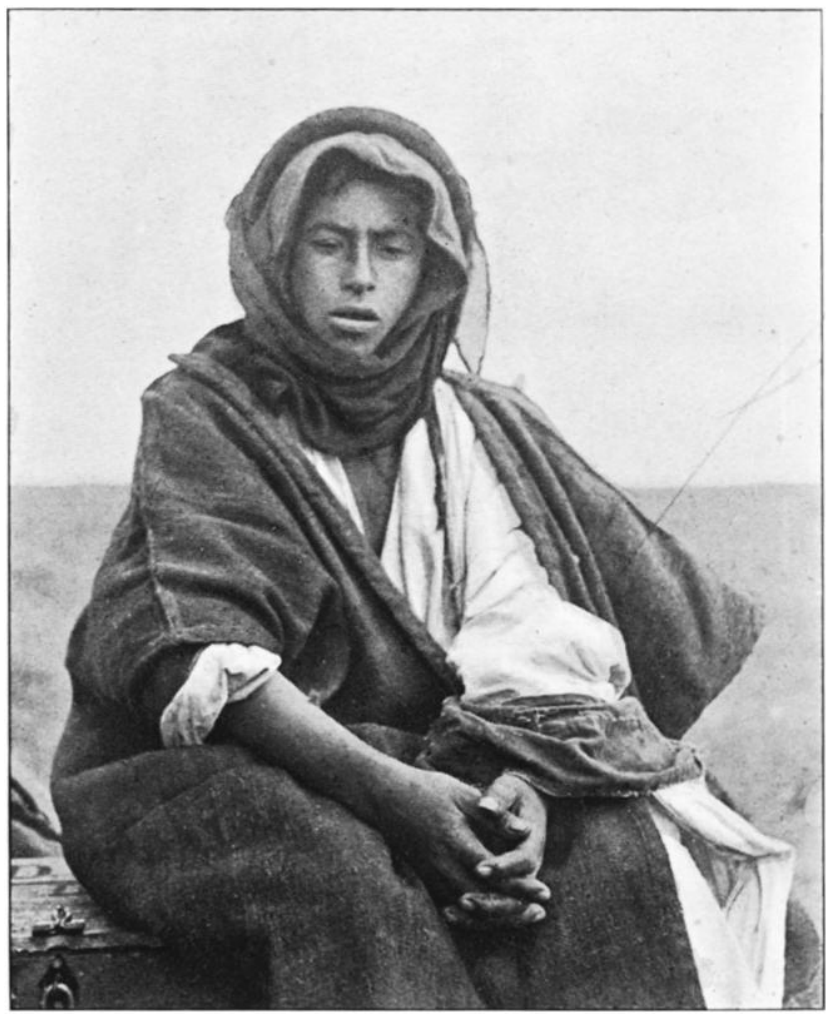

A BEDUIN OF THE SHERRARAT TRIBE.

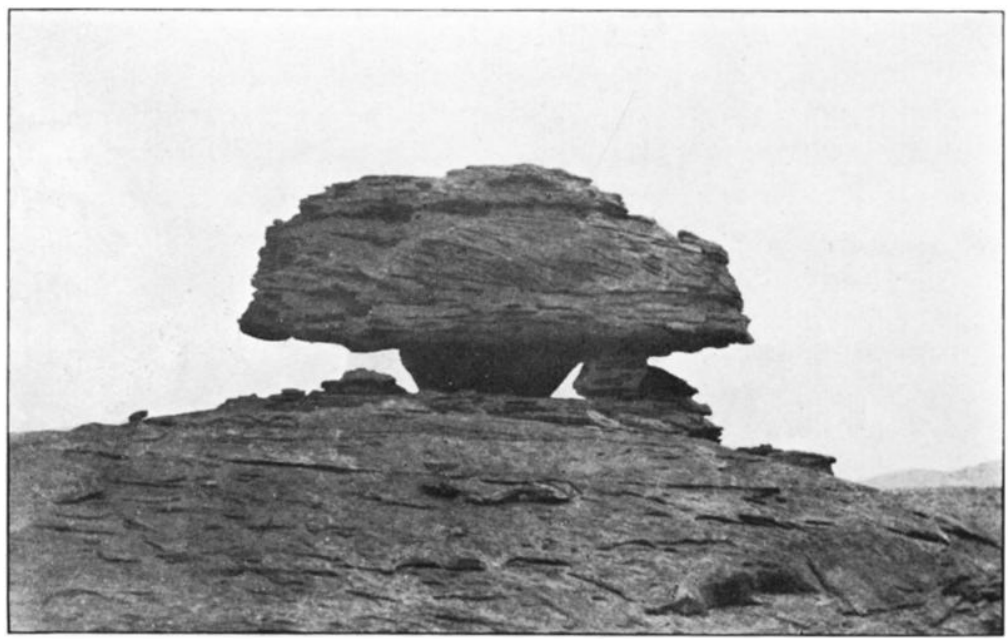

WIND AND SAND-WORN ROCK, WEST OF THE GREAT NAFUD.

This content downloaded from 134.129.182.74 on Fri, 29 Apr 2016 10:22:00 UTC All use subject to http://about.jstor.org/terms 


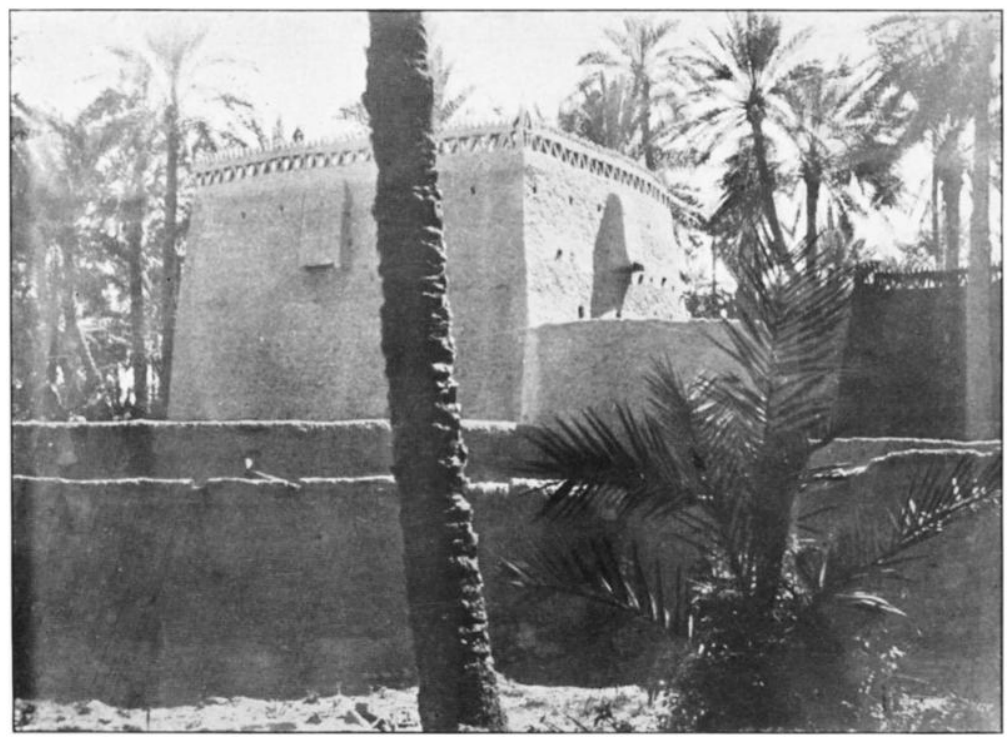

HOUSES IN THE OASIS OF TEIMA.

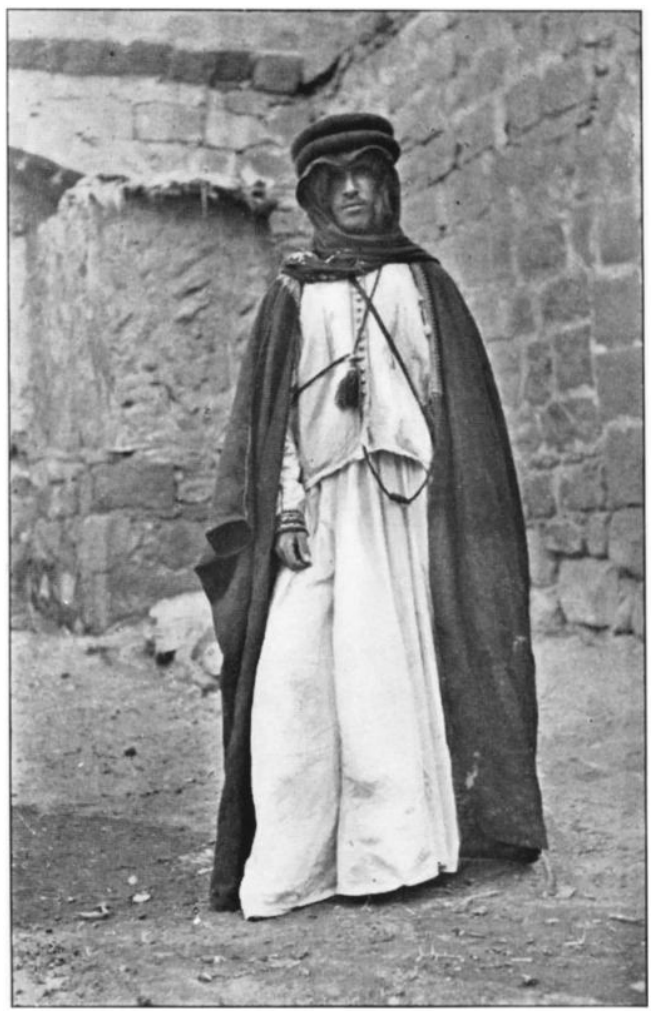

AN ARAB OF TEIMA.

This content downloaded from 134.129.182.74 on Fri, 29 Apr 2016 10:22:00 UTC All use subject to http://about.jstor.org/terms 
be watered at the wells. I was struck with the extreme poverty of these Beduin, for their tents were miserably small, their food was abominable, and the sheikh did not even have any coffee. They possessed some black camels-the first I had seen-and they also had some exceedingly fine white dromedaries. The Sherrarat are considered the most skilful hunters, so I tried to persuade a hunter to accompany me, but they all seemed afraid to go in the direction $I$ indicated because of the Howeitat tribe, who were out raiding.

At this encampment I was paid the greatest compliment that can be offered to any stranger. A young camel having been killed for the evening meal, the women collected the blood in a bowl, and, with a switch of dry grass, they painted long streaks of blood on the necks and flanks of my camels. In the dry climate the blood remained on for a very long time, and acted as a talisman amongst all the Sherrarat Beduin. In this camp I saw the strange sight of a camel carrying large saddle-bags, in one side of which were two babies, and in the other a baby camel!

"Man wants but little here below," but the Sherrarat have reduced their wants to a minimum. A Sherrari I engaged as a hunter possessed nothing in this world except his camel, saddle-bags, rifle, and the clothes he stood up in. He travelled with me for a long time, and never even had an extra covering at nights, although the weather was terribly cold.

The Sherrarat are all very good shots, and it is a common saying amongst the other tribes that a Sharrari is equal to three other men in a fight. Their skill in tracking is also very great, for these nomads, like the Red Indians or the Hottentots, have reduced the practice of tracking to a science. Half the life of a Beduin is spent amongst the camels; from early childhood, when he is sent out to guard the herds, until he is too old to ride out on raiding expeditions, camels form the chief concern of his existence. They are herdsmen by profession. Without the camel, life would be impossible in the deserts of Arabia. Small wonder, then, that camel-talk is as interesting to the Arab as the camel itself. It is his only means of information, and, by constant practice, the true Beduin can read the footprints like a book; they are science and gossip to him. This art is called Athar.

On several occasious when travelling by night my hunter stopped his camel, and, after a short examination of some camel-tracks, exclaimed that it was a raiding party of such a number and of such a tribe, and on each occasion I proved him correct. In daylight he could determine the exact number of camels from a mass of tracks all going in one direction, and could also say how long ago they passed and to what tribe they belonged. Marauding bands always leave a long, straight, compact line of footprints, as of men travelling fast, close together, and with an object. On hard, stony ground, where the camels leave little or no 
impression, the dung tells exactly the time at which the owners passed that way, and probably the nature of the pasture, from which they deduce the extent of their wanderings.

Another most interesting custom of the Sherrarat is their habit of fortune telling. On every possible occasion, when in doubt as to the way, in danger of marauding bands, in want of water, or even when hunting and are in doubt as to the age of an antelope track, they proceed to tell their luck before venturing. It is simply done, by smoothing out the sand and making at hazard several rows of marks in the sand with the fingers. An even number is a bad omen, an odd number a good.

On leaving the wells of Mghairah a new type of country faced us. This was the region immediately west of the Great Nafud sand-desert, where I entered a very weird area of wasted sandstone hills. It was as if the whole country had been swept away by the continual westerly winds that always blow here with great violence. The ground was covered with wind-worn rocks that stood up in hundreds like giant mushrooms. In other places the dominating feature of the landscape was the table-mountains. These are of volcanic core, but outwardly appear to be sandstone. They are black at the summit, whilst the sides are red. Long ages ago the whole desert was at the same level as the top of these hills, but the continual wasting away and drifting of the sand towards the east has lowered the level of the country, and only the hard volcanic spires remain. The result of this wasting has gone to make the great sand-desert that has formed in the centre of Arabia, and which is called "Nafud." The true "parents of the Nafud" are, however, further west than this-the high ranges of wasted sandstone that border the Hedjaz railway.

Passing to the east of the well of Fajr, and safely through a mixed encampment of Roala and Sherrarat, I entered on the last stage of my journey before reaching the first oasis. The land became more barren. There was scarcely any camel-feed at all, neither had I any success at hunting, although I followed one herd of oryx for three days. We found on one occasion the traces of a fight between the Shammar tribesmen and the Roala, which showed that we were getting within the boundaries of the Emir of Hail.

To show how complicated are the intrigues of the various tribes, I might say that the Roala Beduin are enemies with the people of Teima and with the Shammar tribesmen, and yet they are friends with the inhabitants of the oasis of Jauf, who are themselves adherents to the Emir of Hail, and indirectly with the Shammar and Arabs.

On the eighteenth day after leaving the tents of the Beni Sakhr I sighted the oasis of Teima, the first town of any importance in NorthWestern Arabia. The oasis formed a large patch of cultivation in a glaringly white and absolutely sterile basin. We rode down and boldly 
entered the oasis, being entertained by one of the leading families, relations of my Damascene friend who accompanied me.

So far everything had gone well, and I had passed through the Beduin tribes without hindrance, but I had yet to deal with the fanatical settled population of the oasis of the heart of Arabia-the pure-blooded Arabs. My intention was to remain in Teima until I could procure guides and protection for my journey to Hail, but my plans were suddenly upset by the Governor of Teima ordering me to leave the oasis immediately. He also sent his armed servants to turn out all my baggage, and to rob me of all the money they could find. This they did. Finding me quietly sitting in a tent pitched in a garden under the palms, they covered me with revolvers, tore open all my baggage, and took everything that they fancied. They did not find much, however, for I had already taken the precaution of stowing all my valuables in the harem of my host's house, where everything, in Arabia, is as safe as in the Bank of England.

However, on one pretext or another, I managed to remain in Teima five days, in spite of daily warnings from the governor to "quit." He also made insinuating remarks to $m \theta$ as to the fate of the last European who visited their town-Huber-who was here in 1863, and was eventually murdered.

Although the governor, the representative of the Emir of Hail, behaved thus, the inhabitants were, on the other hand, quite friendly. My host proved his Arab hospitality to the fullest limit, and was willing to endanger himself rather than turn away a stranger who had come to his house.

The chief impressions I gathered of this ancient oasis were, the extreme cleanliness of the houses, the great size of their halls, the wonderful water-supply, and, I might also add, the beauty of the women. The halls are of such a size that when occupied by twenty or thirty men they still look empty. The rooms are high and lofty, with roofs of palm or tamarisk rafters, often supported by rows of pillars. I measured one room 40 feet by 30 feet, and 20 feet in height.

The chief sight in Teima is the great well-pit, the El Haddaj, rightly called the "Heart" of Teima, a well famous all over Arabia. It is of such a size, and so great is the flow of water, that ninety camels can draw water at once. By a clever system of skin-buckets and ropes passing over ninety pulley-wheels, this number of camels can work at the same time. Automatically the water is tipped out into stone troughs and is carried to the furthest corners of the oasis by irrigating canals. Day and night the water is being hauled up, and the constant creaking of the water-wheels resounds all over the oasis. Besides this well, there are at least twenty smaller sources.

This water, the natives say, comes from the volcanic country called Harra. It is without doubt a strong spring of pure artesian water, 
which they have chanced to tap, which would otherwise flow unused all the way to the Persian gulf. There is apparently a great deal of water flowing across Arabia, but secreted in the sandstones far below the surface and hidden under its burning sands.

In the depression of Teima the water lies nearer the surface, and is therefore more easy to get at. By means of the water thus made use of, the inhabitants grow the following crops: barley, wheat, and a small quantity of millet; they cultivate the plum, fig, lemon, pomegranates, and gigantic citrons. Grapes they grow in small quantities, and, curiously enough, tobacco-a strange product for an oasis generally considered strong adherents of the Wahabi sect, whose tenets forbid them to indulge in luxuries and the use of tobacco. Dates, however, form the staple food of the inhabitants, and these seem to reach as near perfection as possible in this oasis. The date-stones are ground up and used for camel-food.

Another industry of Teima is the collecting of rock-salt, which is in general use amongst all the tribes of Northern Arabia.

The inhabitants of Teima are of the purest Arab breed, and very handsome in appearance. They appeared to me of almost a pale complexion after the Beduin, but this is not to be wondered at, seeing that they seldom leave the shadow of their palm trees, and never have to endure the burning glare of the desert. The men wore their hair in long curls, or in plaits, and they always shave the upper lip in orthodox Moslem manner, but as a rule they had scanty beards. Their dress varied but little from the Beduin, except that they carried swords instead of rifles. These scimitar-shaped swords were of fine workmanship, made at Hail, and the owners carried them constantly wherever they went. The natives seemed to me to be extremely suspicious, and zealous of guarding their oasis from intruding strangers, and they are just as suspicious of the Turks as of the Christians, especially now that the Hejaz railway passes within a two days' journey of their town. That the oasis of Teima is increasing in size is evident from the new plantations of young palm trees that are appearing on the outskirts of the older cultivation and the new walls encircling them. There is no reason why Teima should not increase in prosperity, for the water-supply is unlimited. The aneroid read 2800, 2900, and 3000 feet whilst I was in Teima, though Mr. Doughty makes it 390 feet higher than this.

It seems impossible to give any estimate of the size of Teima, for there is no large block of houses or bazaar. Each man's house is situated in its own garden, surrounded by a bigh wall. At the time of my visit-the end of February-spring was in evidence at Teima. The plum trees were in blossom and the figs in leaf, and I also noticed many small birds on their northern migration.

Of the affairs of the Emirate of Hail I heard but little. The present 


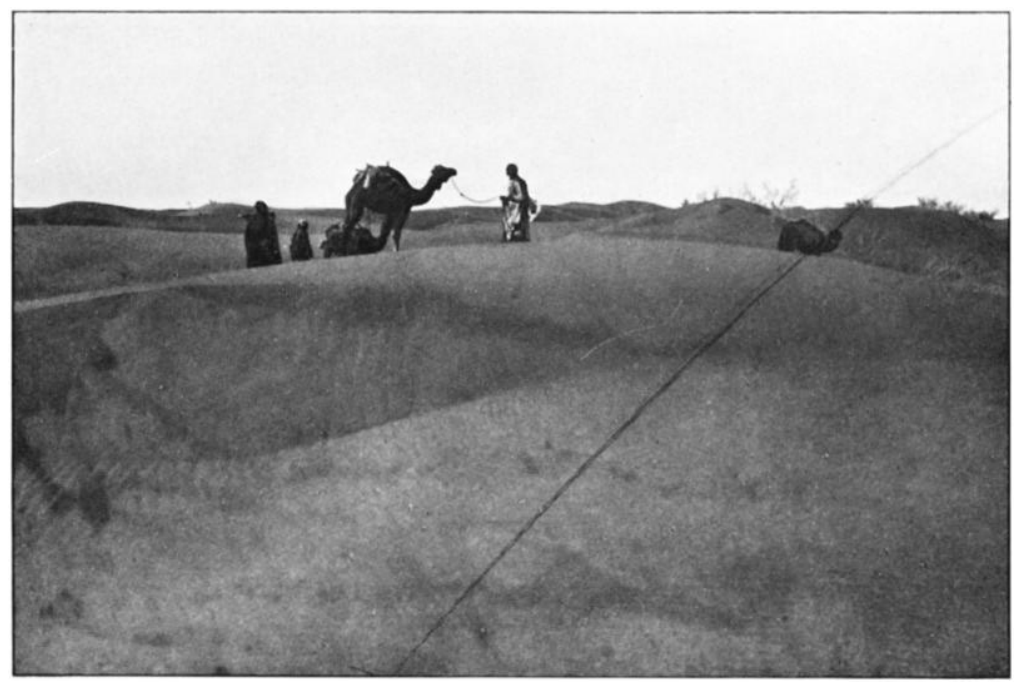

SAND-DUNES IN THE WESTERN NAFUD.

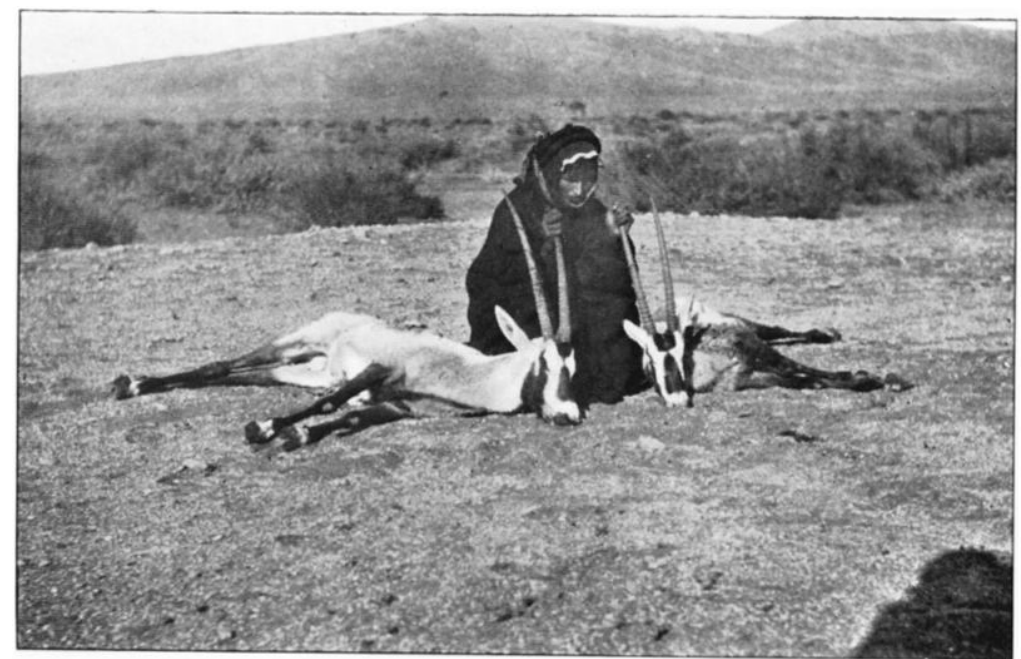

THE ARABIAN ORYX (ORYX BEATRIX), THE "WILD COW" OF THE BEDUIN. 
Emir was a child of twelve years of age; at that time the country was being ruled by his uncle Hamud ibn Sebhan. While I was in Teima this man was killed, and no doubt sleeps with his fathers, whilst his cousin Zamil ibn Sebhan rules in his stead. Of the rival emirs, Ibn Soud was at that moment the stronger.

After five days the attitude of the governor became very threatening, and since I had no guides to accompany me to Hail, and the tribes in that direction were in a more unsettled state than usual, owing to the murder of their leader, I left Teima. Escaping by night, I struck due north and explored the western edge of the Nafud. The southern edge of the sand-dune area has been skirted by a few travellers, but its western limits were unknown.

Passing along its western edge, I determined the limit of the sanddunes in this direction to within two days of the oasis of Jauf. The dunes begin in a most remarkable manner, rising up abruptly above the surrounding desert, so that one can walk in a few paces from the hard stony steppe on to the wild turmoil of sand-hills. At the edge of the dunes, half-way between Teima and Jauf, the aneroid registered 2300 feet, which corresponds exactly with Blunt's observations at the Nafud edge near Jauf. Mr. Doughty's readings on the edge of the dunes between Teima and Hail are much higher than mine, namely, 3495 feet. This greater altitude is accounted for by the fact that the general slope of Arabia is from the south-west to north-east, and that therefore the highest part of the floor of the Nafud is in the region where Doughty took his readings; also the sands themselves lie deeper on the south and south-west than they do on the north and east.

The sand-dune area itself is at a higher altitude than the bordering steppe, and one immediately rises on entering the sand-hills. The aneroid registered 2300 feet on the steppe, and 2600 feet on the first sandridges. Euting gives 960 metres as the altitude of the highest sanddune, and Doughty makes a difference of 575 feet between the steppo and the sand-dunes. Thus the dunes stand up above the true level of the desert to a height of from 300 feet to 500 feet.

The sand-dune area, curiously enough, supports a considerable amount of vegetation, a heavier growth, indeed, than the surrounding desert. The Nafud is covered with the ghada bush, and a tall grass, called "knusi" by the Arabs (Aristida forskahlei), grows in some quantity, and is excellent feed for camels. There are also wide stretches of pure sand without growth. I have measured the roots of the ghada, where the sand has blown away and left them exposed, as 50 feet in length. I also found a curious parasite (Cynomonium coccineum) growing on the roots of the ghada bush, which produced a long spadix of the most brilliant red colour. As these are very juicy and full of water, the antelope that inhabit this waterless region dig in the sand in order to

No. III.-MARCH, 1910.] 
get at them. It is worthy of notice that the Arabian oryx seemed to be most numerous where these parasites were growing. Another plant of parasitic habits found there was the Phelipea lutea.

All the dunes trended in a north-and-south direction, and the sides facing east were generally too steep for the camels to walk down. The sand was red and of an extremely fine texture, and I noticed that on the tiny sand-ripples the summits were composed of large grains, whilst the hollows were filled with very fine particles. I saw nothing of the curious faljes, or great horseshoe pits, which all travellers have remarked on in the centre of the Nafud. In the sand-desert itself there are no wells, but outside its limits on the west I found three, namely, Ubai, Huj, and Imleih. Only the last named was visited, and I found it to contain rather salt water at a depth of 20 feet. There were numerous well-pits. The well of Huj is between this and the Nafud, and is well marked by a hill shaped like a camel-saddle and called Huj Umkur.

'The well of Ubai is also on the Nafud edge north-north-east of Teima. To the east of it there are some sandstone crags emerging out of the sands, called "Theithuwath Assafiyyeh" and "Hulwan Khunfi ;" the latter is identical with Thulla Helwen mentioned by Doughty. These hills, like the crags of Jubbe on the Hail-Jauf route, are probably a confirmation of Euting's statement, as mentioned by $\mathrm{Mr}$. Hogarth, that "the sandstone stratum of the Nafud is not infrequently emergent in the form of Hat-topped hills."

The Roala tribe were camped in this region, and although I only came in contact with a small section of the tribe, I could not help noticing their superiority to the other tribes I had met. They appeared to be remarkably well to do, owning many horses, falcons, and huntingdogs, while their tents were very large and their camels were decorated in a way that suggested wealth.

To show that this region is not entirely without rain, I may record the fact that we came across several pools of rain-water caught and standing in hollow rocks. We should have passed them by unnoticed if it had not been for the camels, who sniffed the water from a considerable distance. This water would remain for several days if there was no wind, but with the least breeze it would soon dry up. There was a small encampment of Beduin near by, dependent on these small pools of rain-water for their drinking supply.

Along the edge of the Nafud I found a few more birds, and obtained samples of a chat (Saxicola morio), three larks (Alæmon desertorum, Ammomanes desertorum, and $A$. cinctum), and the cream-coloured courser ( $C u r$ sorius gallicus). On the sand-dunes I found the broken eggs of the ostrich, and nany small hares. An extremely venomous snake exists in this region, and I obtained one fine specimen. It is a horned viper of a bright sandy colour. But the most interesting fauna was the Arabian oryx, whose 
haunts I had at last found. Here on the western edge of the sanddunes they roamed in considerable numbers, and' $I$ carried off with me five entire skins of these antelope, which had not previously been hunted by Europeans, nor had they even been seen in their natural haunts.

Leaving the Nafud and turning west, I returned to the well of Hausa, passing on the way the borders of the smooth black plain of Bseita. This is identical with the Albuseita mentioned by Wallin in 1848. Although absolutely bare of all vegetation at the time of my visit, I noticed many little circular threshing-floors, where the Beduin prepare the seed called "semh," which grows in great quantity when there is any rain. The semh plant, according to the Arabs, cannot be reprodnced from seed, neither have they ever succeeded in cultivating it. For this reason the Sherrarat call the plant "the gift of the rain." The grain is dried in the sun and ground into flour. This they make into bread, or mix with their dates, or eat as porridge.

The well of Hausa we found to be nearly dry, and, with thirsty camels and empty water-skins, we hurried on, travelling parallel with my out-going track, but on the west of it. This route took me to the wells of Bayer, in Wadi Bayer, where I chanced to fall in with a raiding party of Beduin. They were encamped at the well, on the look-out for Arabs coming in to get water. They at once took my party prisoners, and I should have lost all my possessions if the chief had not happened to be friendly with the tribe of the Beni Sakhr, under whose protection I had set out. I mention this as an example of Beduin chivalry, for the Arabs are still romantic highwaymen rather than bloodthirsty ruffians. They have not degenerated, neither are they illiterate or uncouth, but, on the contrary, exceedingly polite, and have the same powers of eloquence, and the same beauty of speech, which have always distinguished them. These desert-dwellers own no law but custom, and their custom is inviolable.

As a result of my capture by this raiding party, I made a most interesting discovery. The well called Bayer, where the robbers were encamped, is situated in the upper part of Wadi Bayer, some 55 miles east-north-east of the oasis of Maan. Now, this is on the line of the supposed ancient trade route between Egypt and Busra, and, as a proof of such a route having existed, I found at this very well the ruined remains of a large khan, or caravanserai. Such a building as this, far away out in the sterile desert, must denote an ancient prosperity which has long disappeared.

With the decay of Babylonia and the desiccation of Northern Arabia the trade routes naturally fell into disuse. Even the great trade centre of Petra is deserted, and Gerra, the terminus on the Persian gulf, is nothing but a name. Small wonder, then, that the wayside stations have fallen into oblivion. 
This, then, is another link in the chain, and we now have an almost complete series of wells across the middle part of this route, namely, from Petra to Jauf. The stages between these two places are as follows :-

Petra to Maan, 20 miles.

Maan to Wokh, about 25 miles. This is a well and ruined village mentioned by Palgrave.

Wokh to Bayer, 30 miles.

Bayer to Weisit, 95 miles. (I should not be surprised if there is yet another well in this region, together with a ruined site, still undiscovered.)

Weisit to Jauf, 90 miles. This stage is through the Wadi Sirhan, where there are numerous wells.

Of the stage from Jauf to the head of the Persian gulf we know nothing, but on the old maps in the atlas of Ptolemæus, I find placenames at regular intervals, as if indicating the stopping-places on a caravan route.

These details will be of interest to those who propose a railway from Egypt to the Persian gulf. No greater hindrances exist than those already overcome by the builders of the Hejaz railway. As a whole the type of country would be easier than that crossed by the Mecca line, and the physical difficulties less severe.

The objection put forward that the Beduin would prove hostile to the building of the railway is, I think, unfounded. On the Hejaz railway this hostility does exist, it is true. It is partly the result of a weak government, but chiefly because the building of the railway takes away from the Beduins the blackmail which they have imposed from time immemorial on the pilgrim caravans, in return for a safe passage through their territory. Moreover, the trouble usually occurs on the threshold of the Holy provinces, and not on the northern deserts.

Now, if the "Suez-Busra" line was built, the Beduin who inhabit the region through which the line would pass, need not be interfered with in any such way. They would not lose their independence through the building of the railway. The Beduin are not unreasoning barbarians, but are quick to recognize a powerful and just government.

The Hejaz railway is not interfered with by the Beduin, except in the neighbourhood of the Holy provinces, and I have myself seen the strange sight of a band of maurauding Beduin come in to a station on the line in order to get water for their wounded men and horses.

From the wells of Bayer, which, by the way, consisted of two wellpits about 40 feet deep, containing most excellent water, I travelled fast, until I reached the Hejaz railway at Khan Zebib, which is an old Saracenic castle on the pilgrim route. From here I made my way to 
the tents of the Beni Sakhr, and thence by way of the Jordan valley to Damascus.

'The President (before the paper) : Mr. Douglas Carruther's, who has kindly undertaken to lecture to us to-night, has obviously many years' good work kefore hin, though having already done some admirable scientific work. His first exploration of which I have any knowledge was that to Mount Ruwenzori, undertaken under the auspices of the British Museum. After that he went with Mr. Rickmer Rickmers to 'Turkestan, and we may hope to hear later on some of his experiences in those regions. Then he proceeded to Asia Minor, and he will to-night tell us something about his journeys in the lesser-known parts of Arabia. Subsequently he did some excellent work in the Dead sea region. $\mathrm{He}$ is, I understand, about to proceed on other journeys with some well-tried companions, and we may therefore look forward to a great deal more useful work coming from this explorer.

Mr. Hogarth: If I must begin the discussion, I shall avail myself of the opportunity to congratulate Mr. Carruthers on having made an exceedingly interesting journey, and on having come safely back. I think you will all agree with me that he has spoken with rare sympathy and insight about that most interesting people, the nomadic people of Arabia. It is the people of romance par excellence, wandering for ever in the most God-forsaken country in the world. The Beduins on the west side of the delta have a story that the Creator actually forgot them in the creation. At the same time, as I think Mr. Carruthers has shown you, they are a very highly chivalrous people among whom it is not really difficult to travel if you observe their ways and keep the rules. Arabs appear to live by robbing one another, but that practice is carried on according to certain rules, which make it really very like playing a game-a great rough game like football, perhaps not even so rough as football after the American fashion. It is but rarely that many are kilied at it, and I am glad to hear Mr. Carruthers bear his witness that the raider does not go out in the first instance to kill. There is one interesting feature of the game-that, in the case of battle near an encampment, it is a recognized thing that neither party enters the camp. 'The fight is carried on according to certain rules well a way from the camp, and does not endanger the lives of the women and children, who are left behind to look after the camels.

Mr. Carruthers has been exceedingly modest about what he achieved, and it is of course true that he only got a very short way into Arabia; but he travelled over a road which has not been travelled before, so far as I know, and only one man (whom he mentioned), the Italian Guarmani, who was one time a consul in Jerusalem, has travelled over a tract of country near that which he took. Guarmani's account of his journey is extremely short and unsatisfactory, and, perhaps I might add, there has always been a certain doubt as to whether he took that journey at all. Mr. Doughty, at any rate, who has every reason to be heard with the deepest respect, has always refused to accept the fact of Guarmani's visit to Kheibar. I must congratulate the company on having been present to-night, when these photographs of one of the interior oases of Arabia have been put for the first time on the screen. They were very admirable photographs, and, indeed, I have not seen better of nomadic Beduins before. 'They seem to represent the life as really and as intimately as Mr. Carruthers' own account shows he had seen it. If he was not in any great danger in passing through the Beduin tribes, his dangers, as you see, began when he got into the first of the oases. That has always been the case in Arabia. It is perfectly true, as he said, that the oasis peoples are much more 


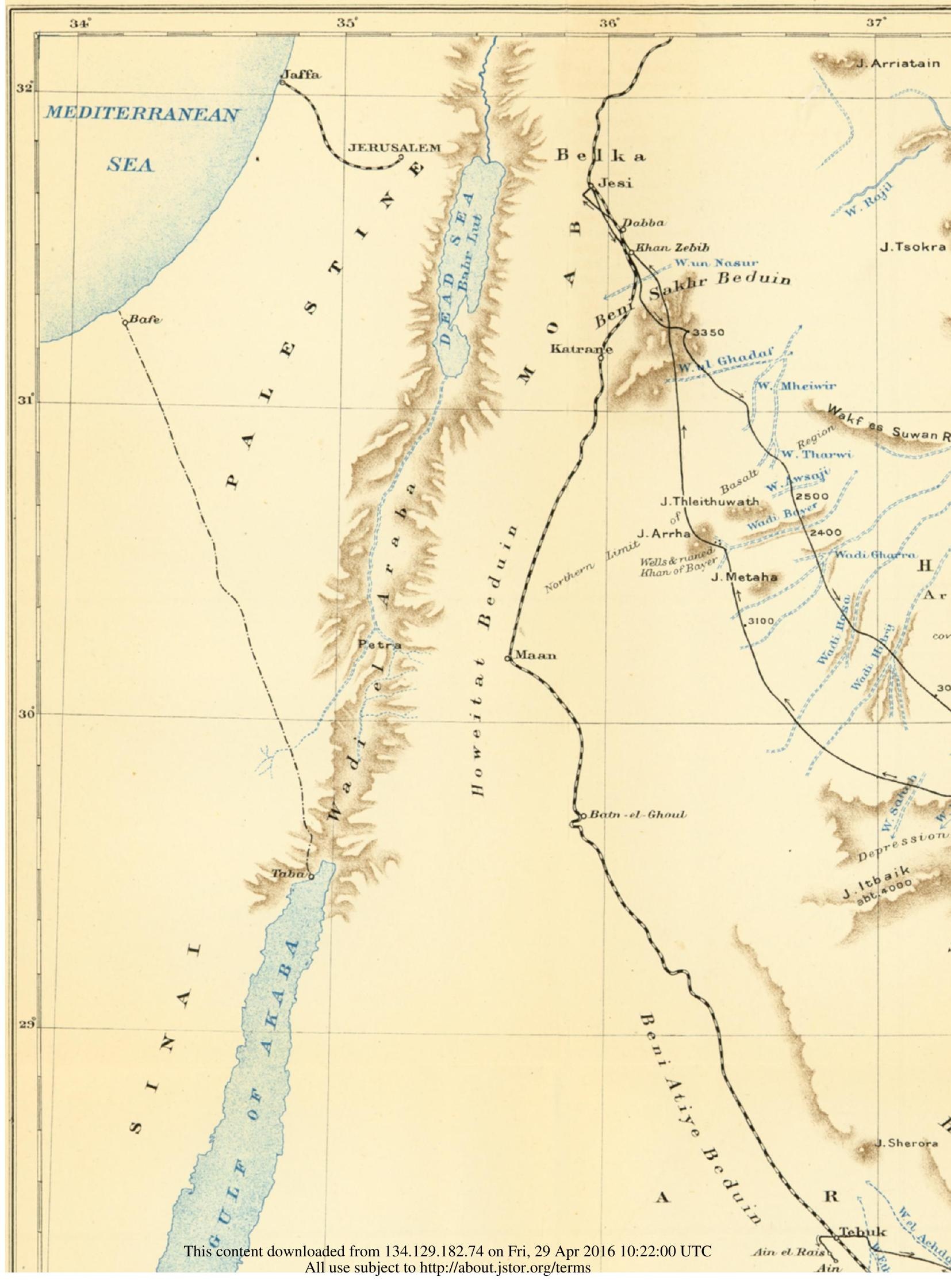




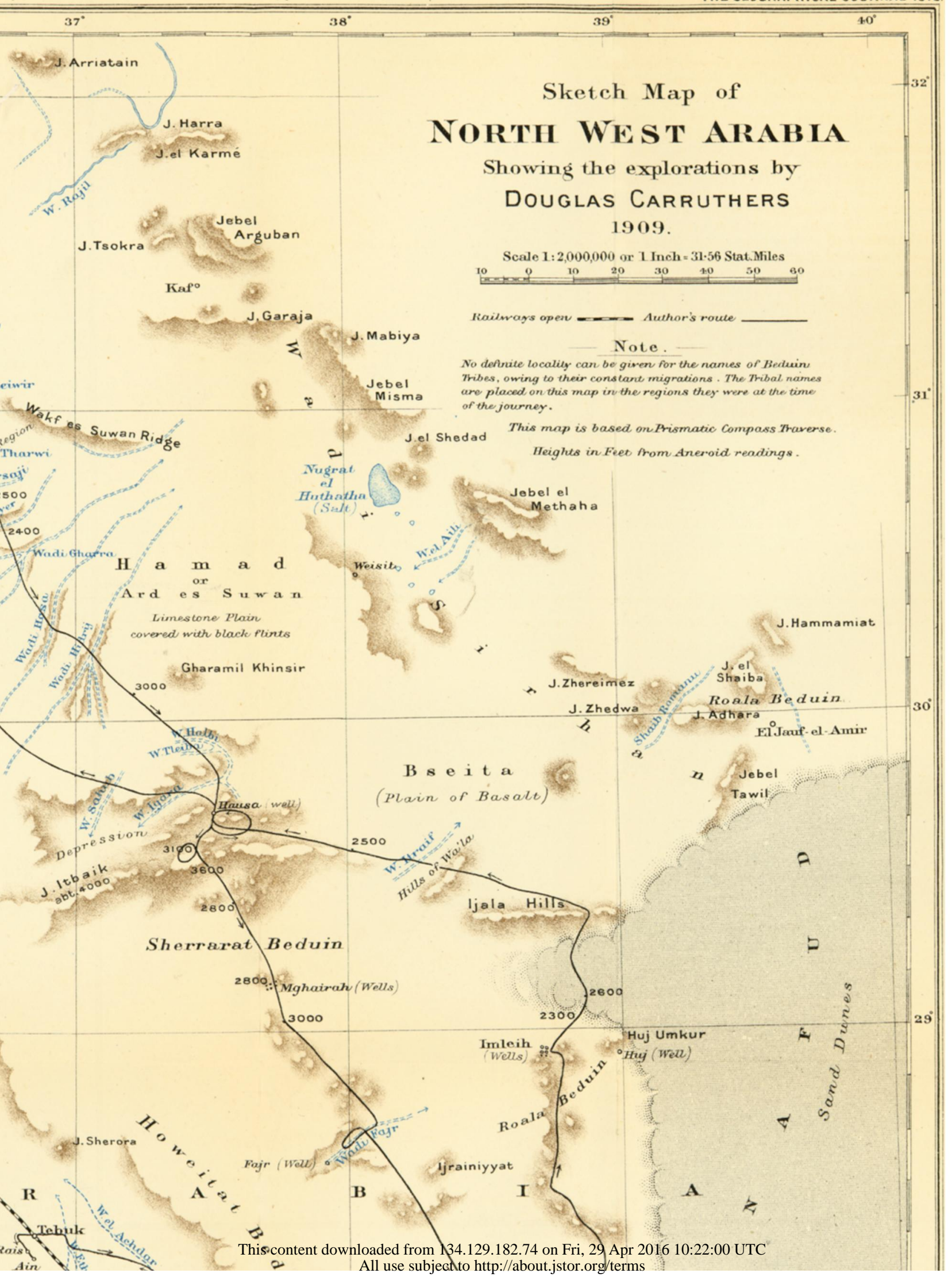


